\title{
Marxism and Latin American Literature
}

Ritwik Ghosh

PhD Department of English

St. Xavier's University

Kolkata, West Bengal, India

ritwik.ghosh1@gmail.com

In the aftermath of the collapse of the U.S.S.R Marxism remains a viable and flourishing tradition of literary and cultural criticism. Marx believed economic and social forces shape human consciousness, and that the internal contradictions in capitalism would lead to its demise. ${ }^{\mathrm{i}}$ Marxist analyses can show how class interests operate through cultural forms. ${ }^{\text {ii }}$ Marxist interpretations of cultural life have been done by critics such as C.L.R James and Raymond Williams. ${ }^{\text {ii }}$

Marx was a communist who proclaimed the proletarian revolution and worked in the 1840 's to transform the League of the Just into the Communist League. ${ }^{\text {iv }}$ It was for this group that Marx helped write The Communist Manifesto in late 1847 and like all his political associations this was like an international forum for the creation of information and views. ${ }^{\mathrm{V} E n g e l s}$ supported the Marx family in London. ${ }^{\mathrm{vi}}$ In 1852, Marx summarized his own contribution to political ideas in three points, the third point being that the dictatorship of the proletariat is a transition to a communist form of society that would be classless and would promote the free development of individuals. ${ }^{\text {vii }}$ Marx challenged moral philosophers with his view that morality resided in ideology. ${ }^{\text {vii }}$ Marxism is meant to be a synthesis of theory and 
practice. ${ }^{\text {ix }}$ To Marx a society is capitalist if the production of material goods is dominated by the use of wage labour. ${ }^{\mathrm{x}}$ In The German Ideology, Marx claims that idea propagating institutions are also controlled by the economically dominant class. ${ }^{\mathrm{xi}}$

For Marx alienation is the condition in which the creations rule the creators, where the creators become the victims of their creative powers. ${ }^{\text {xii }}$ For Marx religion is an example of alienated thinking. ${ }^{\text {xii }}$ Capitalism prevents us from valuing the world in any but the most instrumental manner. ${ }^{\text {xiv }}$ The abolition of capitalist alienation would restore our senses to the complexity of sensuous life. ${ }^{\mathrm{xv}}$ In abolishing capitalism the world becomes an object of appreciation rather than exploitation. ${ }^{\mathrm{xvi}}$ Marx insists on joining the artistic and economic realms. ${ }^{x v i i}$ Marx in combining the artistic and economic into a seamless entity makes artistic activity a part of all other human production. ${ }^{\text {xviii }}$ In the Marxist view artistic productions such as paintings or literature are not essentially different from the production of cars or computers. ${ }^{\text {xix }}$ Marx talks about artistic phenomena in practical and historical terms. ${ }^{\mathrm{xx}}$ Marx argues that all forms of consciousness including art are conditioned by productive practices. ${ }^{x x i}$ Marx claims that there is a direct linkage between the aesthetic sensibility of a society and its mode of production. ${ }^{\text {xii }}$

Marx claims that the development of technology and the development of the division of labour correlates to the artistic forms in a society. ${ }^{\text {xxiii }}$ For Marx artistic expression works within the forms of consciousness appropriate to a societies productive practices and relations. ${ }^{\text {xxiv }}$ Flaubert's novels are from a Marxist perspective ideological in representing the particular societal productive practices of a specific society and time. ${ }^{\mathrm{xxv}}$ To Marx art is a form of ideology and is conditioned by class conflicts and differences. ${ }^{\mathrm{xxvi}}$ For Marx culture is part of the system of power and reproduces the topography of societal conflict. ${ }^{x x v i i}$ Marx considers art as an ideology 
as it articulates the shared sensibilities and collective desires of a culture. ${ }^{\text {xxviii }}$ Marxists aim to historicize artistic forms, and to connect aesthetic sensibilities to specific forms of social life. ${ }^{\text {xxix }}$ For Marx the distinction between high and low art is a marker of class differences. ${ }^{\mathrm{xx}}$ From a Marxist perspective aesthetic judgments are mechanisms of social exclusion and inequality. ${ }^{\mathrm{xxi}}$ For Marxists the dominant artistic forms embody the consciousness of the dominant class. ${ }^{\text {xxii }}$ In Marx's vision of aesthetics, works of art have political functions in their form and content, which serve to legitimate the social order from which they arrive. ${ }^{x x i i i}$ Marx describes in The German Ideology the idea that class consciousness tends to obscure the relations between the material and cultural world, and in doing so represent historically contingent ideas as universal and timeless truths. ${ }^{\text {xxxiv }}$ Marx in the critique of political economy in Capital concentrates on the problem of "fetishism" which is the tendency of various forms of thought, from religion to political economy to naturalize the social world, rendering it as a realm of natural laws to which human beings are helplessly subject. ${ }^{\mathrm{xxv}}$ The political function of these illusions is to represent historically specific interests and social arrangements as inclusive and universal. ${ }^{x x v i}$ Class rule makes attempts to legitimate its power by investing it with the illusion of universality and necessity. ${ }^{\text {xxxvii }}$

In the Marxist perspectives works of art ought to be analyzed for their legitimating functions, for the ways in which they attempt to universalize and rationalize contingent social and historical relations. ${ }^{\text {xxxiii }}$ The ideological function of art is complex and yet fundamental to art. $^{\text {xxxix }}$ Frederic Jameson is a major figure in the quest to develop a Marxist theory of literary criticism. Jameson is concerned with the "negative hermeneutics" of Marxism, whose task is to unmask artworks, to show how art and cultural artifacts have specific ideological missions in legitimating power structures and creating forms of false consciousness. ${ }^{\mathrm{xl}}$ The ideological 
function of an artwork does not lie on its surface, but somewhere deeper. ${ }^{\text {xli }}$ Jameson is concerned with the political unconscious of artworks, on how class perspectives are inscribed in literary works in their narrative structures and strategies. ${ }^{x \text { lii }}$ To Jameson the aesthetic act is itself ideological, and artworks serve the ideological function of making social contradictions appear invisible, seem imaginary or more bearable. ${ }^{\text {xliii }}$ To Jameson literary works create the legitimation of the social contradictions of class society by constructing symbolic, imaginary worlds that offer unrealistic solutions and gratify desires that are suppressed by the social order. ${ }^{\text {xliv }}$ Marxist readings ought to counter the legitimating function of literary works by producing alternative readings. ${ }^{\text {xlv }}$ For Marx art is a privileged model of human activity and is also a form of socially conditioned ideological consciousness. ${ }^{x l v i}$ For Marx the realist novel can help to describe the features and characteristics of class ideology. ${ }^{x l v i i}$ The realist novel is in a sense close to ethnography. ${ }^{\text {xlviii }}$ The ability to identify the covert operations of ideology in art works is a step towards revolutionary political practices. ${ }^{\text {xlix }}$ Art is a form of political learning and can be a site for the critique of ideology. ${ }^{1}$

For Herbert Marcuse the central feature of art is its subversive power. ${ }^{\text {i }}$ For Marcuse, all true art is inevitably subversive, as the act of imagining alternative realities, shake us out of

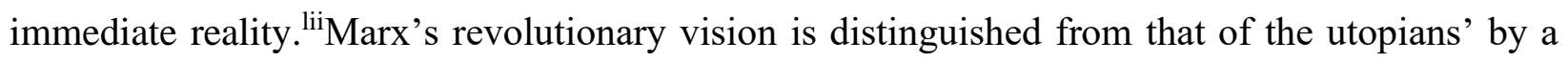
refusal to set one dimensional projections. ${ }^{\text {liii }}$ Marx's thinking is aesthetic in its claim that the fullest human life is that of free creative practice. ${ }^{\text {liv }}$ For Marx a proper human society is one where the productive apparatus sets free the creative powers of the producers. ${ }^{\text {lv }}$ To Marx human creativity is the aim of productive life. ${ }^{\text {lvi }}$ For Marx fetishism is part of the strategy of the legitimation of class domination and exploitation. .vii $^{\text {vii }}$ 
A Marxist society would nurture creative sensibilities that would be liberated and would be part of a liberated social order where the creator gains control of the creation. ${ }^{\text {lvii }}$ The goal of revolutionary practice is to turn the aim of liberating the creative sensibilities into social practices that would be new and liberating patterns of labour. ${ }^{\text {lix }}$ A truly liberated society would be one where work would no longer be based on exchange labour, but would be its own end, giving creative satisfaction and enhancing the creative sensibilities of the workers. ${ }^{1 \mathrm{x}}$ In a Marxist society work would be like art, in that the worker like the artist, would not be alienated from the work or craft. ${ }^{1 x i}$ Marx is against the division of labour, which the model of the artist is against. Artistic production, as a model implies a highly individualized relationship between the producer and product, thereby giving the process of artistic production wholeness and unity. ${ }^{\text {lxii }}$ Marx's aesthetic sensibilities are formed around a highly individualized model of artistic production. ${ }^{\text {.xiii }}$

Marx in his later work talks about the liberation of the individual from the demands of the productive realm itself, and the maximization of leisure. ${ }^{\text {lxiv }}$ For Marx, revolutionary society will be cooperatively and consciously planned by the producers. ${ }^{\text {lxv }}$ The revolutionary aim of the new social order ought to be liberating the senses, abolishing the maximization of profits and the reduction of socially necessary labour time. ${ }^{\text {lxvi }}$ The revolutionary world aims at the creation of leisure, and the aesthetic model of artistic creation and satisfaction through the creator reappropriating creation is an example of revolutionary practice. ${ }^{\text {xvii }}$ Creativity is opposed to alienation, the fragmentation and mechanization of labour and the aesthetic is a way to imagine revolutionary futures.

The Marxist author Bertolt Brecht promoted a Marxist theory of art based on distrust of entertainment and pleasure removed from critical thought and scrutiny. ${ }^{\text {lxviii }}$ Brecht promotes an “estrangement effect" that as a cultural practice challenges audiences to think. ${ }^{\text {lxix }}$.Marxists look 
at works of literature as products of collective, social and political conditions. ${ }^{\text {xx }}$ The Marxist analysis of history and its influence on literature and cultural products applies broadly across time and geography. ${ }^{\text {lxxi }}$ Marx believed that the global overthrow of capitalism would be a step towards the abolition of classes and the realization of a world without power relations that create antagonism, scarcity and class division. ${ }^{\text {lxxii }}$ Christopher Caudwell attempted to explain the rise of works of culture such as poetry, while adhering to revolutionary politics. ${ }^{\text {lxxiii }}$

G. V. Plekhanov, an early Marxist, worked to develop Marxism as a systematic theory, and in do so rejected the notion of great individuals as a significant model for the study of history. ${ }^{\text {lxxiv }}$ Plekhanov's devaluation of the individual artist allows for and enhances the study of art as a function of society and time. ${ }^{\operatorname{lxx}}$

Theodor Adorno, a figure of the Frankfurt school thought that the commodification of art undermined its critical potential. ${ }^{\text {lxxvi }}$ Walter Benjamin in his essay "The Work of Art in an Age of Mechanical Reproduction" gives an optimistic evaluation of the transformation of art under technology, even with potential dangers and difficulties. ${ }^{\text {lxxvii }}$ Benjamin perceives that the technologically determined relationship between art and spectators is of political significance. $^{\text {lxxviii }}$ Benjamin is aware of the distinctive political possibilities in the fascist and communist approaches to art, created by the transformed relationship between art and spectator brought about by technology. ${ }^{\text {lxxix }}$ For Benjamin, the removal of the unique features of art liberates everyone to politicize art rather than revere it as an object or source of authority. ${ }^{\operatorname{lxx}}$ Marxism challenges the idea that art is neutral, making us aware of the transformations in technology that alter social relations around art, generating new political dangers and possibilities for political revolutionary practice. ${ }^{\text {lxxxi }}$ 
Georg Lukacs developed a Hegelian quasi-utopian formulation that when the working class becomes conscious of its needs and objectives it overcomes the alienation between the world of objects and that of subjects. ${ }^{\text {lxxii }}$ Theodor Adorno and Max Horkheimer in their 1947 work Dialectic of Enlightenment attack what they call the "culture industry" referring to the capitalist institutions that produce popular culture to the masses as commodities. ${ }^{\text {lxxiii }}$ They argue that popular culture and entertainment ideologically enslave the masses and they reject film, jazz and much of literature and art. ${ }^{\text {lxxiv }}$

The comments by Marx and Engels on art and literature are scattered and fragmented. ${ }^{\text {lxxxv }}$ The originality of Marxist criticism lies in its revolutionary understanding of history. ${ }^{\text {lxxxvi }}$ For Marx the function of ideology is to legitimate the power of the ruling class and the dominant ideas of a society are the ideas of its ruling class. ${ }^{\text {lxxxvii }}$ In Marxist thought art is part of the 'superstructure' of society and is part of a society's ideology. ${ }^{\text {lxxxviii }}$ Ideology is the social perception that ensures that the situation in which social classes have power over one another is

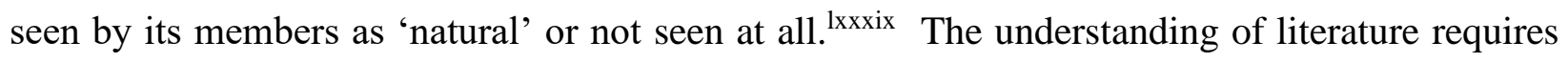
understanding the social process of which it is a part, and understanding the ways in which literature displays ideology in how class relations are experienced, legitimized and extended. ${ }^{\mathrm{xc}}$ To understand ideology it is necessary to analyze the precise relationships between different classes in a given society, in relation to the mode of production, and class domination and exploitation. ${ }^{\text {xci }}$

Althusser argues that art has a particular relationship to ideology. ${ }^{\text {xcii }}$ For Althusser ideology has structural coherence and can be the object of scientific analysis as can literary texts as they are objects of ideology. ${ }^{\text {xiii }}$ A Marxist scientific criticism would explain the literary work in terms of its ideological structure, and would show how the work is tied to ideology as well as 
distanced from it. ${ }^{\text {xciv }}$ Marxist criticism is on occasion interested in the formal structure of literature.

The Hungarian Marxist critic Georg Lukacs was interested in form. Many Marxists have opposed literary formalism for neglecting the historical and social aspects of literature by focusing on its technical aspects. ${ }^{\mathrm{xcv}}$ Marx argued for the unity of form and content and in this was faithful to the Hegelian tradition of aesthetic philosophy he inherited. ${ }^{x c v i}$ While Marx disagreed with Hegel on many aesthetic issues, both share the belief that artist form is determined not by the individual but by history and society. ${ }^{\text {xcvii }}$ For Marxists artistic form is historically determined. ${ }^{\text {xcviii }}$ Marxist criticism sees form and content as dialectically related and asserts the priority of content in determining form. ${ }^{\text {xcix }}$ Marxists adopt a dialectical conception of the form-content relationship and attacks the Russian formalists for being concerned with the technical aspects of literature instead of the ideology of its content. ${ }^{c}$ For Marxists the true bearer of ideology in art is form rather more than content. ${ }^{\text {ci }}$ Marxism states that developments in literary form are a result of changes in ideology. ${ }^{\text {cii }}$ Plekhanov argues that the transition from classical tragedy to sentimental comedy in France reflects a shift from aristocratic to bourgeois values. ${ }^{\text {cii }}$

Marxist criticism calls on the writer to commit art to the cause of the proletariat. ${ }^{\text {civ }}$ In the 1934 Congress of Soviet Writers, 'Socialist realism' was adopted as official doctrine. ${ }^{\text {cv }}$ Lenin thought that Tolstoy had an incorrect understanding of history, as he did not recognize that the future lies with the proletariat and as he was a spokesman for petty-bourgeois peasant interests. ${ }^{\text {cvi }}$ Trotsky opposed the Futurists' naïve discarding of tradition, insisting like Lenin on the need for socialist culture to absorb the products of bourgeois art. ${ }^{\text {cvii }}$ Trotsky believed that counter-revolutionary works ought not to be tolerated and believed in a vigilant revolutionary censorship. ${ }^{\text {cviii }}$ Socialist art ought to be 'realist' and realism is intrinsically neither revolutionary 
nor reactionary. ${ }^{\text {cix }}$ Trotsky berates the Formalists for their unconcern for the social content and conditions of literature. ${ }^{\mathrm{cx}}$

Russian 'revolutionary democratic' critics like Belinsky, Chernyshevsky and Dobrolyubov saw literature as social criticism and analysis, and the artist as a social enlightener. ${ }^{\text {cxi }}$ Plekhanov believed that only art which serves history rather than immediate pleasure is valuable. ${ }^{\text {cxii }}$ For Plekhanov the writer translates social facts into literary ones, and the task of the literary critic is to decode them back into reality. ${ }^{\text {cxiii }}$ Through Belinsky and Plekhanov the idea of literature as socially reflective enters into the formulation of socialist realism. ${ }^{\text {cxiv }}$ Marx liked realist, satirical and radical writers, and was hostile to romanticism which he regarded as a poetical mystification of political reality. ${ }^{\mathrm{cxv}}$

Socialist realism prescribes that literature should teach certain political attitudes and assumes that literature reflects social reality. ${ }^{\text {cxvi }}$ Lukacs in his late work on Marxist aesthetics sees artistic consciousness as a creative intervention into the world rather than a mere reflection of it. ${ }^{\text {cxvii }}$ For Macherey the effect of literature is to deform rather than to imitate and literature is essentially parodic. ${ }^{\text {cxviii }}$ Lukacs argues that writers should do more than merely reflect the despair of bourgeois society, they should try to take a critical perspective on it, revealing positive possibilities beyond it and they should do more than merely society. ${ }^{\text {cxix }}$ George Thompson studied how Greek drama embodies changing economic and political forms of Greek society, and believed that the artist's role is to collect a store of social energy, created from a libertory fantasy which makes people refuse to acquiesce in the conditions of the world as it is. ${ }^{\mathrm{cxx}}$

Marx recognizes that literature is an industry and that writers are workers. ${ }^{\text {cxxi }}$ Walter Benjamin believes that the revolutionary artist should not uncritically accept the existing forces of artistic production, but should revolutionize those forces. ${ }^{\text {cxxii }}$ For Benjamin the truly 
revolutionary artist is not concerned with the art object alone, but with the means of its production. ${ }^{\text {cxxiii }}$ The revolutionary artist reconstructs artistic forms. ${ }^{\text {cxxiv }}$

Walter Benjamin states that the mechanical reproduction of art creates a plurality of copies which destroys any alienating aura and allows the viewer to encounter the work in the viewers own time and place. ${ }^{\text {cxxv }}$ For Brecht the task of theatre is not to reflect a fixed reality but to show how character and action are historically produced, and ought to make audiences reflect critically on the mode of representation and actions which are represented. ${ }^{\text {cxxvi }}$ Brecht's 'epic' theatre displays Benjamin's theory of revolutionary art as one which transforms the modes of artistic production. ${ }^{\text {cxxvii }}$ Marxist literary criticism is part of the liberation from oppression. ${ }^{\text {cxxviii }}$

Marxism as a theoretical perspective may be useful in the analysis of the literature of Latin America, which is a literature written in Spanish, Portuguese and Amerindian languages. Latin American history in the discovery and Conquest of the America's by Columbus was violent, marked by slavery, war and disease. Colonization brought with it the destruction of native peoples both physically and culturally. The Spanish language through its hegemonic dominance became a language that was used by writers of native Amerindian heritage as well. Spanish was a language through which the evangelization of the native Amerindians took place.

The Napoleonic wars catalyzed the process of decolonization. The process was violent and was more so in the Spanish American colonies. Enlightenment philosophy was an inspiration for the independence movements.

Marxist analysis may be efficacious in understanding slavery in Latin America, the caudillo phenomenon, populism in Argentina, the Cuban revolution, the genocide in Guatemala of the indigenous Mayans, and the dirty wars in Argentina, Chile and other Latin American countries. 
The dirty wars in Argentina and Chile were part of the larger ideological struggles of the cold war, and it is this larger ideational framework, which has significant social implications, that make a Marxist approach to the literature produced in and after the dirty wars a worthwhile enterprise. Military regimes during the dirty wars attempted to wipe out their real and perceived enemies. The ideological polarization of society gave military regimes the motivation to commit terror and carnage. The Chilean and Argentine states developed surveillance and torture techniques. The Juntas in Chile and Argentina controlled and censored the news and media.

The development of the struggle for human rights in Argentina is connected with the Madres de la Plazo de Mayo, who were a group of mothers who demanded the return of their missing children in Argentina's most public space, the Plaza de Mayo.

To understand the dirty wars and its effects on literature, it is necessary to connect the testimonies, conversations and writings of survivors of state terror, with works of fiction such as the many novels, short stories and poems that have been and are being written. To analyze the discursive and ideological practices at play in both non fictional and fictional works, it is helpful to understand how ideology has been constructed, used and manipulated. Understanding the Marxist motivations of those who fought against and were persecuted by the military regimes and their terror is a step towards gaining a fuller picture of historical memory in Latin America, as well as in our understanding of state terror, torture and genocide across world history.

' Leitch, Vincent B, General Editor. The Norton Anthology of Theory and Criticism: Second Edition. W.W. Norton \& Company, 2010, pp. 648.

ii Ibid., pp. 649.

iii Ibid., pp. 650.

iv Carver, Terrell, editor. The Cambridge Companion to Marx. Cambridge University Press, 1991, pp. 9.

vibid., pp. 9.

vi Ibid.

vii Ibid.

viii Ibid., pp. 19.

ix Ibid., pp. 30.

x Ibid., pp. 55. 


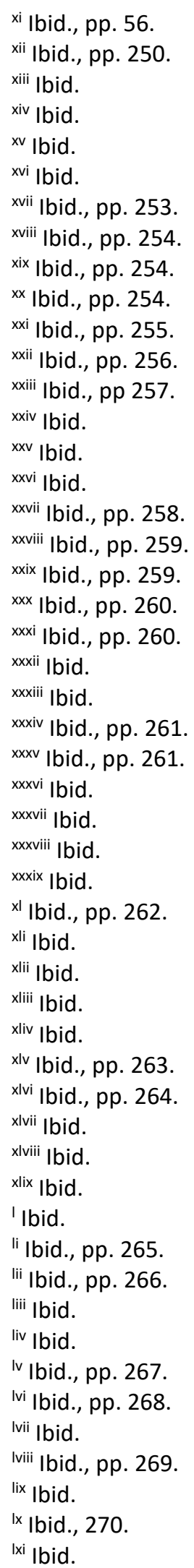


Ixii Ibid.

Ixiii Ibid.

Ixiv Ibid., pp. 271.

Ixv Ibid., pp .272.

Ixvi Ibid.

Ixvii Ibid.

Ixviii Anshen, David. Marxist Literary and Cultural Theory. Orient BlackSwan, 2017, pp.23.

Ixix Ibid., pp. 23.

Ixx Ibid., pp. 47.

Ixxi Ibid., pp. 48.

Ixxii Ibid.

Ixxiii Ibid., pp. 89.

Ixxiv Ibid., pp. 84.

Ixxv Ibid., pp. 85.

Ixxvi Ibid., pp. 94.

Ixxvii Ibid.

Ixxviii Ibid.

Ixxix Ibid.

Ixxx Ibid., pp. 95.

Ixxxi Ibid.

Ixxxii Ibid., pp. 116.

Ixxxiii Ibid., pp. 131.

Ixxxiv Ibid., pp. 132.

Ixxxv Eagleton, Terry. Marxism and Literary Criticism. Taylor \& Francis e-Library, 2006, pp. 1.

Ixxxvi Ibid., pp. 2.

Ixxxvii Ibid., pp. 3.

Ixxxviii Ibid., pp. 3.

Ixxxix Ibid.

xc Ibid.

xci Ibid.

xcii lbid., pp. 9.

xciii Ibid.

xciv Ibid.

xcv Ibid., pp. 10.

xcvi Ibid.

xcvii Ibid., pp. 11.

xcviii Ibid.

xcix Ibid.

${ }^{c}$ Ibid.

ci Ibid., pp. 11-12.

cii Ibid., pp. 12.

ciii Ibid.

civ Ibid., pp.18.

cv Ibid.

cvi Ibid., pp. 20.

cvii Ibid.

cviii Ibid.

cix Ibid.

cx Ibid.

cxi Ibid., pp. 21.

cxii Ibid. 
cxiii Ibid.

cxiv Ibid.

cxv Ibid.

cxvi Ibid., pp. 23.

cxvii Ibis., pp. 24.

cxviii Ibid.

cxix Ibid.

cxx Ibid., pp.26.

cxxi Ibid., pp 28.

cxxii Ibid., pp 29.

cxxiii Ibid.

cxxiv Ibid.

cxxv Ibid.

cxxvi Ibid., pp. 30.

cxxvii Ibid., pp. 31.

cxxviii Ibid., pp. 35. 


\section{Bibliography}

Anshen, David. Marxist Literary and Cultural Theory. Orient BlackSwan, 2017.

Carver, Terrell, editor. The Cambridge Companion to Marx. Cambridge University Press, 1991.

Eagleton, Terry. Marxism and Literary Criticism. Taylor \& Francis e-Library, 2006.

Leitch, Vincent B, General Editor. The Norton Anthology of Theory and Criticism: Second Edition. W.W. Norton \& Company, 2010. 